\title{
The Spanish banks' strategies in Latin America
}

\section{Alvaro Calderón}

Economic Affairs Officer, Division of Production,

Productivity and Management, Business Strategies and Investments Unit, ECLAC acalderon@eclac.cl

\section{Ramón Casilda}

Director of Strategy,

Norsistemas, Unión Fenosa

Group, Probanca, Madrid.

Consultant to the Inter-

American Development Bank

rcasilda@norsistemas.es
After more than ten years of a broad-ranging and extensive process of financial liberalization and deregulation, the Latin American picture in the banking, insurance and pension fund markets has been significantly changed by the massive presence of globalized financial institutions. The major Spanish banks have been among the main actors in this respect and have become leading figures in most countries and business segments. From the Latin American standpoint, the entry of foreign banks, especially those of Spain, has helped to invigorate and modernize the financial systems of the region; has brought in new instruments and technologies; has increased competition, with direct effects on access to credit and its cost, and has given the local financial systems greater strength and stability. However, it has also given rise to some difficulties, such as greater concentration and only a very slow process of handing on to clients the benefits of the greater competition and efficiency achieved in the Latin American financial markets. This extensive presence of Spanish banks, together with the active expansion of Spanish non-financial companies in the main Latin American markets, has revealed the limitations of the local regulatory frameworks for coping with the growing globalization of international markets. Thus, decisions taken in Europe affect users in Latin America, causing reactions at various levels whose results will only become evident in the future. 


\section{I}

\section{Introduction}

The profound changes undergone by the economies of the region -openness, liberalization and deregulation- have given rise to a new business environment in Latin America which provides easier access for foreign investors. In the 1990s, foreign direct investment (FDI) flows to Latin America and the Caribbean registered unprecedented growth rates, rising from US\$ 9.2 billion in 1990 to nearly US\$ 86 billion in 1999 (ECLAC, 2000). This means that over $65 \%$ of the present stock of FDI entered in the 1990s. In practice, then, foreign investments in the region have been almost completely renewed. This phenomenon has been marked by major changes in the origin, destination and strategies of foreign investors (ECLAC, 2000; Calderón and Vodusek, 1998:

- Although foreign investors' interest has continued to be centered on the biggest economies of the region, they have shown gradually increasing interest in the smaller countries.

- $\quad$ The generalized predominance of United States companies is beginning to be offset by the massive arrival of European companies, mainly from Spain, the United Kingdom, the Netherlands and France.

- Investments in manufacturing activities have been replaced by investments in services, especially telecommunications, retail trade, energy and finance. This has given rise to a massive inflow of companies which are setting up operations in Latin America for the first time.

- Foreign investors have mostly resorted to the purchase of existing assets to enter the region or expand their presence in it, first through the extensive privatization programmes and later through the acquisition of local private firms.

The authors wish to express their thanks for the valuable comments made by their ECLAC colleagues Gunther Held, Jorge Katz, Georgina Núñez, Michael Mortimore and Luisa Rangel and also by Octavio de Barros, Chief Economist of BBV Brasil, Alfredo Arahuetes of the Spanish Centre for Latin American Studies (CEDEAL), Elisa Domínguez de McKinsey Madrid, Matías Kulfas of the Centre for Production Studies (CEP) of the Ministry of the Economy and Public Works and Services of Argentina, and Christian Feres of the Association for Research and Specialization on Ibero-American Subjects (AIETI).
In this new setting, Spanish companies have become leading actors. After having been almost totally absent at the beginning of the 1990s, now, at the end of the decade, Spain has become the second largest investor in the region and the largest investor of European origin (Calderón, 1999a). In this period, the largest Spanish companies concentrated their expansion strategy on the services area of Latin America, through the acquisition of existing assets, in order to cope with the challenges posed by the creation of the Single Market and a common currency in Europe (figure 1).

Major Spanish investments in Latin America began in the early 1990s with the strong presence of Telefónica and Iberia in the privatization processes of the region; subsequently they were further strengthened with the entry of Endesa España and Repsol in the middle of the decade, and they took on really large dimensions with the acquisition strategy implemented by banking institutions from 1996 on (figure 1). In aggregate terms, the financial sector (mainly banks and insurance) has been the main direct Spanish investor abroad, only exceeded recently by big investments of the telecommunications and energy companies: the participation of Telefónica de España in the privatization of the Telebras system in mid-1998 and the assumption by Repsol and Endesa España of the control and management of the biggest private energy companies of Argentina and Chile (Yacimientos Petrolíferos Fiscales (YPF) and Enersis, respectively) early in 1999 (Calderón, 1999b).

The largest Spanish banks have invested nearly US\$ 10 billion in their Latin American expansion process. Thus, Banco Bilbao Vizcaya (BBV), Banco Santander and Banco Central Hispano $(\mathrm{BCH})$-the last two of which recently merged-saw a unique opportunity in the region to attain dimensions that would allow them to compete better in the demanding international financial markets and thus maintain their identity, diversify risks, and defend themselves against possible hostile takeover bids by competitors. 
FIGURE 1

Spain: Evolution of direct investments abroad, 1980-1998

(Millions of dollars)

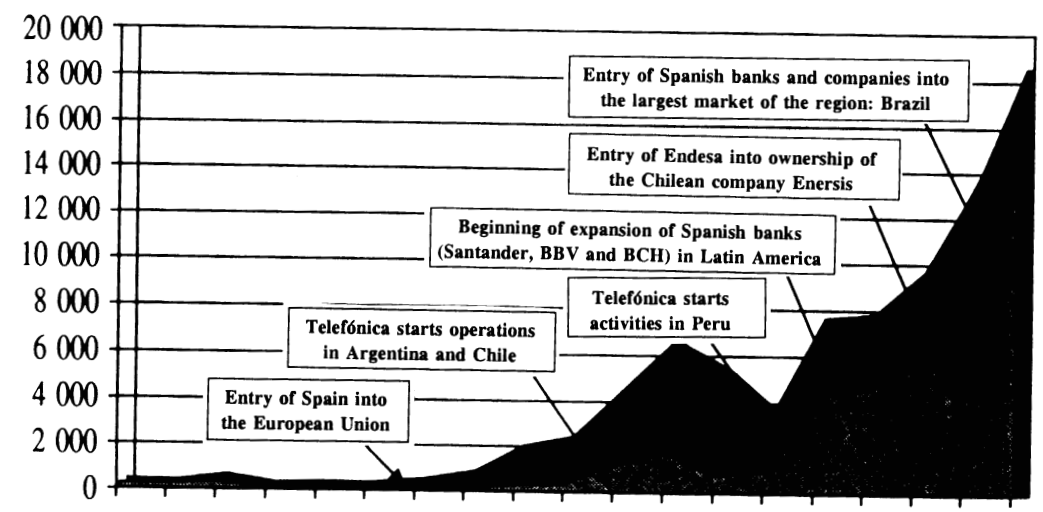

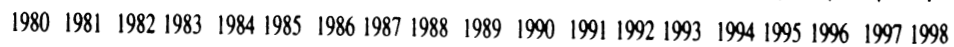

Latin America and the Caribbean

Total, worldwide

Source: ECLAC, Information Centre of the Business Strategies and Investments Unit of the Division of Production, Productivity and Management, on the basis of data from the Dirección General de Economía Internacional y Transacciones Exteriores (DGEITE) of the Ministry of the Economy and Finance of Spain.

\section{II}

\section{The changes in the Spanish banking system}

In the mid-1970s the Spanish authorities began a process of liberalization and deregulation of financial activities. From 1985 on, the process of change in the Spanish banking system speeded up with the incorporation of new technologies, products and consumer habits, the increase in dis-intermediation, and the entry of Spain into the European Union (EU). Subsequently, the changes in the structure and strategies of the financial institutions became still more radical with the formation of the Single European Market and the beginning of the process of economic and monetary union in preparation for the entry into use of the single currency, the Euro.

At the beginning of the 1980s, the Spanish banking sector was content to satisfy the existing demand for basic products in a context of limited competition. During the 1980s, however, the profound changes which took place brought the market to the verge of total saturation, there was a considerable in- crease in competition, and the private banks were obliged to redefine their strategies to satisfy the demands and needs of their clients (persons, companies and institutions). Thus, the system changed from a product-oriented to a client-oriented banking system: a process which has been typical of the financial innovation phenomenon worldwide (Casilda, Lamothe and Monjas, 1997).

In this situation, the banks were mainly concerned with maintaining their levels of profitability, to which end they made significant cuts in their operating costs. They reduced the number of banking institutions (concentration increased through mergers), they made staff cuts, and they reduced the number of branches in their local networks. At the end of the 1980s, competition in the Spanish banking system began to become really marked, with consequent differences in the strategies adopted by the different institutions. This process was heightened when the 
Banco Santander brought out a high-yield current account called "SuperCuenta": 1 an initiative which was quickly copied by the other banks.

The establishment of the Single European Market meant the elimination of barriers to the free circulation of capital among the member countries of the European Union, as well as freedom to establish and provide banking services. Thus, the financial sector in both Spain and the rest of the European Union began to develop new growth and concentration strategies in order to adapt to this new competitive environment. On 1 January 1993, with the entry into force of a set of directives drafted by the European Council on the free circulation of capital and the creation of Community-wide financial institutions through a single banking licence, formal European Union regulations came into effect for the credit institutions market. On 14 July 1995, by Royal Decree, the Spanish Government incorporated these Community regulations into the national financial legislation.

Important multilateral commitments have also been entered into with regard to financial services, and these have speeded up changes in the strategies of the main institutions and national markets, at both the regional and world level. In December 1997 the negotiations (also known as the Fifth Protocol) on financial services were completed in the World Trade Organization (WTO).

The banking market has begun to move from a form of competition based on geographical proximity and the provision of free services to another more generalized form marked by aggressive competition in price policies and the supply of products and services (Casilda, 1997). We thus see that the single currency situation has obliged banking institutions either to achieve the necessary economies of scale (size) or to offer competitive advantages in a particular segment of the market (specialization).

Since the end of the 1980s, the large banks have followed a growth strategy based on mergers and acquisitions, for two reasons: to strengthen their market presence (first at the national level and later internationally) and to increase their competitiveness. In

\footnotetext{
${ }^{1}$ The SuperCuenta was the first current account to pay interest on the balance, and it allowed the Banco Santander to increase its market share by $50 \%$. This product was followed by others, such as SuperDepósitos and SuperHipotecas, which forced the main Spanish banks to engage in a new round of competition, both in products and in market shares.
}

1988 the Banco de Bilbao and the Banco de Vizcaya merged to form the Banco Bilbao Vizcaya (BBV), and this was followed in 1991 by the fusion of the Banco Central with the Banco Hispano to form the Banco Central Hispano (BCH) and the establishment of the Spanish Banking Corporation (Argentaria); ${ }^{2}$ in 1994 the Banco Santander took control of the Banco Español de Crédito (Banesto), and in 1998 the Banco Exterior de España (BEX), the Caja Postal and the Banco Hipotecario merged with Argentaria. At the beginning of 1999 the Banco Santander and the $\mathrm{BCH}$ merged to form one of the largest banking institutions in Europe, the Banco Santander Central Hispano (BSCH), and in October of the same year the BBV and Argentaria merged to form the second largest Spanish bank, the Banco Bilbao Vizcaya Argentaria (BBVA).

This process has brought the Spanish banking market to an increasingly high level of concentration which is now one of the highest in Europe. The market share of the five largest banks grew from $33 \%$ in 1987 to $50 \%$ in 1996. In the latter year, the corresponding levels of concentration were $41 \%$ in France, $35 \%$ in Italy, $28 \%$ in the United Kingdom and 25\% in Germany (Casilda, Lamothe and Monjas, 1997). At the end of 1999, the two largest Spanish institutions (BSCH and BBVA) had 37\% and 30\% respectively of the credit and deposits market (Expansión, 1999a). Parallel with this process, as expected, there was an increase in both efficiency and competition (basically as a result of the ongoing decline in intermediation spreads), which furthered modernization, innovation and improved service to clients.

At the same time, this policy of mergers and acquisitions allowed the large banks to attain a suitable size for embarking on a strategy of internationalization. In the case of Spain, this process has been centered on Portugal, France, Italy, Morocco and especially Latin America. Likewise, and in parallel, there has been an increase in the signing of cooperation agreements between institutions of different Community member countries in order to defend themselves against the competition of the great banks which have been growing up as truly European-scale institutions. Thus, some of the biggest

\footnotetext{
${ }^{2}$ Argentaria grouped together the entire public banking system. Its privatization was fully completed in 1998 .
} 
Spanish banks have sought to extend their presence to other markets through alliances and the purchase of minority shares in other European institutions.

In this respect, the BBV acquired $10 \%$ of the Banca Nazionale del Lavoro (BNL), 3.8\% of the French bank Crédit Lyonnais, and a securities company in Portugal (Midas); the Banco Santander bought nearly $5 \%$ of the Italian institution San Paolo-IMI and $10 \%$ of the Royal Bank of Scotland; the $\mathrm{BCH}$ had minor shares in Commerzbank (3\%) and Société Générale (1.2\%) and, until its merger with the Banco Santander, a strategic alliance with the Banco Comercial Português (BCP); and Argentaria had a strategic alliance with the Franco-Belgian group Dexia. Furthermore, at the end of 1999 the $\mathrm{BSCH}$ and the Portuguese group Champalimaud were negotiating a strategic alliance and the new Spanish institution increased its share in Société Générale to $3.3 \%$ and in San Paolo-IMI to $6.9 \%$ (figure 2). Early in 2000 there was speculation about a strategic alliance between the BBVA and the third largest Italian institution UniCredito Italiano. If this operation were to be completed successfully, it would form the biggest European trans-border alliance (The Economist, 1999; Expansión, 1999b).

In the increasingly competitive context resulting from both economic and financial globalization in general and the establishment of the Single Market and single currency in Europe, however, it is extremely likely that the pressures on the Spanish banking system will increase. Indeed, there has been an increase in the participation of foreign investors in the main Spanish banking institutions. In this situation, it could happen that the local banking institutions might also begin to acquire more and more shares in foreign banks, even to the point of outright purchase or mergers.

In view of these trends, many analysts thought it likely that great European banks with a generalized presence in the markets of the main Community countries would arise. So far, however, this process has not taken place as strongly as expected. In the case of Spain, the foreign banks have not managed to seriously challenge local institutions for leadership of the market, even though there are no major restrictions affecting them in this respect. The network of branches of the Spanish banks is a difficult barrier for new entrants to overcome, since they must make heavy investments in order to gain access to their potential clients. In fact, foreign banks have not secured
FIGURE 2

Relations of ownership between banking institutions of Spain, France, Portugal and Italy, December $1999^{a}$

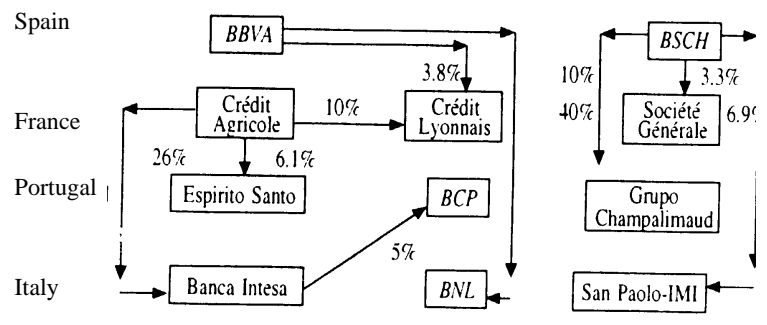

Source: Prepared by the authors on the basis of Cinco Días: Diario de Economía y Empresa, Comisión Nacional de Mercado de Valores, and the Madrid stock exchange.

a BBVA: Banco Bilbao Vizcaya Argentaria; BSCH: Banco Santander Central Hispano; BCP: Banco Comercial Português, and BNL: Banca Nazionale del Lavoro.

significant market shares in any European Union country. Likewise, no bank of a Community country occupies a leading position anywhere except in its country of origin. Consequently, for the Spanish banks and for most of the other European institutions in their countries of origin, physical proximity to their clients continues to be a clear competitive advantage. It is precisely this feature which justifies the concern over possible hostile takeovers of Spanish banks by their European competitors, since this strategy would give the latter easy access to a leading position in the Spanish banking market.

The launching of the Euro on 1 January 1999 has speeded up changes and reduced time horizons, thus changing the expansion strategies of the main European banks. In a first phase, it is expected that in the next five years mergers will be mainly between banks of the same nationality, since cross-border mergers are more complicated on account of differences of language, culture and tax and regulatory systems. Thus, the leading European banks will try to strengthen their position in their local markets -seeking a minimum critical size- in order to face the continent-wide challenge later. During 1999, af- 
ter the formal appearance of the single currency, various large mergers and acquisitions have been announced in a number of countries of the Community (Spain, France, Italy and Germany) for a total of over US\$ 120 billion. $^{3}$ If successful, each of these offers would create large national banks that would be in a strong position to compete for leadership in Europe.

\section{III}

\section{The internationalization of the Spanish banks: the Latin American option}

At the beginning of the 1990s, the banks of the industrialized countries had capital surpluses and were under very strong pressure to reduce costs and take measures to cope with the narrowing of profit margins in their markets - most of them mature and with little capacity for growth-, so that an interesting process of international expansion began to heat up still further (Calderón and Casilda, 1999). The big Spanish institutions went beyond national borders in search of continental- and world-scale markets, both in order to maintain and strengthen their competitive position and in order to defend themselves against possible hostile takeover bids by local or external competitors. In a first stage there was an increase in alliances and collaboration agreements with other institutions, mostly from the Community. In a second stage a rapid and aggressive strategy of expansion into the main Latin American markets was put into effect. The big Spanish banks saw in Latin America the means of consolidating their active internationalization process, based on four main criteria:

i) the search for greater size and competitiveness;

ii) entry into expanding markets, with a consequent shift out of mature markets (as the Spanish market was beginning to be);

iii) exploitation to the full of organizational and technological resources and capabilities; and

iv) suitable diversification of risks as a function of profitability.

In this sense, the Latin American countries offered a unique opportunity, as the closest options, such as those of other European countries, had mature markets and the possibilities for the acquisition of banks in them were very limited and expensive. Generally speaking, the financial systems of the main Latin American countries were marked by considerable openness and deregulation. Thus, the low level of development of banking in the region, the broad intermediation spreads, the high potential levels of profitability and the improvements made in bank supervision and regulation systems began to open up interesting opportunities for new business. At the same time, there was a clear lack of capital and of new products to satisfy a growing demand for financial services. For their part, the banks and economic authorities of Latin America took a positive view of the arrival of foreign partners, as a means of overcoming the shortage of finance and thus strengthening and modernizing the local financial systems. All this was heightened by the context of a common language, culture and history, whose absence was a limiting factor in other situations but whose presence in this case favoured the transfer not only of capital but also of technology and management know-how.

In this state of affairs, the Spanish banks secured a rapid and extensive presence in the main economies of the region, leading the way in the increasing penetration of the Latin American financial systems by foreign banks. Between 1996 and 1998 the share of foreign banks in total deposits rose from $16 \%$ to $30 \%$ (Salomon Smith Barney, 1998). Nearly 60\% of loans and $50 \%$ of the total worth of the banking systems of the seven biggest economies of the region are controlled to some extent by foreign institutions (Salomon Smith Barney, 1999). Only three such institutions (BBVA, BSCH and Citicorp), however, are

\footnotetext{
${ }^{3}$ In Spain mergers took place between Banco Santander and $\mathrm{BCH}$ and between BBV and Argentaria; in France a new institution was formed by the merger of the Banque Nationale de Paris (BNP) with Société Générale and Paribas; and in Italy there were offers by UniCredito Italiano $\mathrm{SpA}$ for Banca Commerciale Italiana and by San Paolo-IMI for Banca di Roma SpA. In Germany there were increasingly strong rumours of a possible merger between the Dresdner Bank AG and the Bayerische Hypotheken-und-Vereinsbank AG.
} 
TABLE 1

Latin America: Importance of foreign banks in selected countries, 1998

(Millions of dollars and percentages)

\begin{tabular}{|c|c|c|c|c|c|}
\hline & \multirow[b]{2}{*}{ Total assets } & \multicolumn{2}{|c|}{$\begin{array}{l}\% \text { foreign ownership } \\
\text { of assets }\end{array}$} & \multicolumn{2}{|c|}{ Main foreign banks } \\
\hline & & $\begin{array}{l}\text { Participation } \\
\text { in equity }\end{array}$ & $\begin{array}{l}\text { Effective } \\
\text { control }^{\text {b }}\end{array}$ & $\begin{array}{c}\text { Spanish (\% of } \\
\text { total foreign banks) }\end{array}$ & Others \\
\hline Argentina & 160363 & 43.2 & 51.5 & $\begin{array}{l}\text { BSCH and BBVA } \\
(39 \%)\end{array}$ & $\begin{array}{l}\text { Bank Boston, Hong Kong and } \\
\text { Shanghai Banking Corporation } \\
\text { (HSBC), Banca Nazionale del } \\
\text { Lavoro, Bank of America, Bank } \\
\text { of Nova Scotia, Chase, } \\
\text { Citibanik, ABN Amro, } \\
\text { Deutsche Bank }\end{array}$ \\
\hline Brazil $^{\mathrm{d}}$ & 627395 & 19.2 & 21.4 & $\begin{array}{l}\text { BSCH and BBVA } \\
(6 \%)\end{array}$ & $\begin{array}{l}\text { ABN Amro, HSBC, Bank Boston, } \\
\text { Citibank, Crédit Commercial de } \\
\text { France, Sudameris, Lloyds Bank }\end{array}$ \\
\hline Chile & 108546 & 39.4 & 35.9 & $\begin{array}{l}\text { BSCH and BBVA } \\
(46 \%)\end{array}$ & $\begin{array}{l}\text { Bank of Nova Scotia, Citibank, } \\
\text { Bank Boston, ABN Amro }\end{array}$ \\
\hline Colombia & 30945 & 21.5 & 28.8 & $\begin{array}{l}\text { BBVA and BSCH } \\
(59 \%)\end{array}$ & Citibank, Banque Sudameris \\
\hline Mexico & 117160 & 19.0 & 16.0 & $\begin{array}{l}\text { BSCH and BBVA } \\
(33 \%)\end{array}$ & $\begin{array}{l}\text { Bank of Montreal, HSBC, } \\
\text { Citibank, JP Morgan, } \\
\text { Bank of Nova Scotia }\end{array}$ \\
\hline Peru & 22074 & 39.8 & 58.5 & $\begin{array}{l}\text { BSCH and BBVA } \\
(38 \%)\end{array}$ & Banque Sudameris, Citibank, \\
\hline Venezuela & 22430 & 32.4 & 40.2 & $\begin{array}{l}\text { BBVA and BSCH } \\
(34 \%)\end{array}$ & Bank of Nova Scotia, Citibank, \\
\hline
\end{tabular}

Source: Prepared by the authors on the basis of information from Salomon Smith Barney, 1998 and 1999.

${ }^{a}$ Refers to share of foreign banks in the assets of local institutions.

b Refers to share in the management of local banking institutions of foreign origin (40\% or more of equity owned by a foreign bank).

c Total assets of banks with Spanish participation, as a share of total assets of all local banks with foreign participation.

d In Brazil, the State banks continue to be very important. This situation should change in the next few years, however, with the privatization of some of the large State banks.

present in all of them ${ }^{4}$ (Durán, 1999). In recent months, despite the international financial crisis and its effects on Brazil and the other economies of the region, foreign financial institutions have continued to invest in Latin America. At present, the biggest Spanish institutions own almost one-third of the assets of the 20 biggest foreign banks (ECLAC, 2000), which means that they alone exceed the share of the United States banks, which have historically been the leaders in this sector in the region (table 1).

In Latin America, rather than playing their traditional role of accompanying non-financial enter-

\footnotetext{
${ }^{4}$ It should be noted that the main foreign banks in Latin America are not those with the broadest international presence. Twelve out of the 20 leading banks in the region occupy rankings below 50 at the international level (The Banker, 1999). Almost two-thirds $(65.3 \%)$ of the total value of the assets of these 20 banks correspond to European Union countries, while United States banks have a smaller share $(29.7 \%)$. Participation by foreign banks is most concentrated in the Southern Cone countries and least so in Mexico (ECLAC, 2000).
}

prises in their internationalization process by providing them with finance and financial services, what the Spanish banks have done is to carry out an expansion strategy within their main area of activity -commercial banking- by trying to achieve a presence in the largest possible number of markets. With this aim in view, but using different strategies, the main Spanish institutions (BBV, Santander, BCH) have invested some US\$ 10 billion in the region (Calderón and Casilda, 1999). At the same time, the main Spanish institutions have carried out an active plan for diversification and the search for new business in the Latin America. Among the types of new business they have engaged in are investment banking, insurance and in particular participation in pension fund management. In addition, as in Spain, they have acquired minority shares in some non-financial enterprises, basically in sectors where other Spanish investors are very active (telecommunications and energy). 


\section{Banco Bilbao Vizcaya Argentaria: Can Latin America be a means for seeking a leading position in the Europe of the Euro?}

At the end of 1998 the BBV, which is both a bank and an economic group, was one of the most important financial institutions in Europe. As a bank, it was the leader in terms of both assets and profits, while as a financial group it was second in size and first in results (BBV, 1999a). At that time the BBV had $17 \%$ of the Spanish market in terms of assets. Early in 1995, it decided to carry out a thorough reorientation of its international strategy, giving a decided boost to its expansion abroad. Now, although $52 \%$ of its activities are in Spain, the BBV Group is present in 35 countries, especially in Latin America. The internationalization process has been quite rapid, and the Latin American region has been given growing importance in it. In 1998 Latin America accounted for $25 \%$ of the group's total assets, $40 \%$ of its branches, and $63 \%$ of its total number of jobs, contrasting with only minimal activity four years before.

The BBV's strategy has been to gradually gain management control of the institutions incorporated into it, without insisting on having a majority share of the equity. It has also tended to give priority to consensus and shared management with its local partners (Burns and Weeks, 1998). A central element in the strategy of this Spanish institution has been to position itself at the head of each of the markets, segments and lines of business in which it competes (BBV, 1999a). To this end, it has acted on two fronts: on the one hand, through the overall growth and development of existing activities, and on the other, through a policy of acquisitions which has allowed it to speed up its growth rate in those markets where it has deemed it necessary to make special efforts.

Over the last four years the BBV has expanded all over Latin America. It has made investments in new markets by buying shares in local banks, has strengthened its position in markets where it was already present, and it has increased its controlling shares in various local institutions. In 1995 it took over the management of banks in Mexico and Peru, a year later in Colombia and Argentina, then in Venezuela, and in 1998 in Brazil and Chile (table 2). It has also developed a unified model for the management of different institutions, adapted to the special features of each financial system and each country.

During 1998 the BBV practically put the finishing touches to its positioning phase in Latin Amer- ica, where it now has a sound and significant presence in the main regional markets. In general, it has invested in leading banks which guarantee minimum profit levels of over 20\% (Uriarte, 1997), whose market shares in their respective countries are over $6 \%$, and whose solvency is sufficiently ample (BBV, 1999a). In 1999 the BBV's profits increased by $25 \%$ to US\$ 1.2 billion, of which US\$ 274 million came from its operations in the region (an increase of over $70 \%$ compared with 1997).

At the end of 1998 the BBV Group's total assets exceeded US\$ 157 billion -twice the gross domestic product of Chile and nearly half that of Argentinarepresenting an increase of $5.5 \%$ over the previous year. This increase was due basically to the incorporation of new acquisitions in Brazil and Chile and expansion in Puerto Rico, which together represented a contribution of US\$ 11.3 billion. These acquisitions meant an increase of over $21 \%$ in total assets in the region, which come to over US\$ 43,026 million. However, the evolution of the local currency values of its assets abroad, especially in Latin America, meant a decline of US\$ 6.34 billion in the total assets of the Group (BBV, 1999a).

According to BBV authorities, the Group has not yet reached a fully satisfactory market share in Brazil and Chile. This is due to the fact that it only began to operate in those countries in recent years and to the special features of those markets: the large size of the Brazilian market and the heavy competition on the domestic market in Chile. Depending on the opportunities that arise, BBV will probably make further investments in these two important Latin American markets: indeed, this Spanish group has the capacity to increase its investment in Latin America from US\$ 1 billion to US\$ 1.5 billion in the next two or three years. The group's entry into Mexico, for its part, has become one of the BBV's most successful ventures, in spite of the difficulties through which the local financial market is passing. The BBV Group has invested some US\$ 700 million in capital, infrastructure, technological development and staff training in that country, and has become one of the most solvent institutions in the area (Hernández, 1999).

One of the most important objectives of the BBV's strategy has been to increase its value on the stock exchange. In this respect, the value of its stock has increased more than the average for its main domestic and European competitors, despite the difficult international conditions. This situation has been reflected in the ongoing positive evaluation of this 
TABLE 2

Bilbao Vizcaya Argentaria group: ${ }^{\text {a }}$

Presence in the Latin American banking market, 1999

(Percentages and millions of dollars)

\begin{tabular}{|c|c|c|c|c|c|c|}
\hline & Local bank & $\%$ ownership & $\begin{array}{l}\text { Position in } \\
\text { local banking } \\
\text { system }\end{array}$ & $\begin{array}{c}\text { Total value } \\
\text { of assets, } \\
\text { December } 1998\end{array}$ & Year of entry & $\begin{array}{l}\text { Purchase } \\
\text { price }\end{array}$ \\
\hline \multirow[t]{2}{*}{ Argentina } & BBV Banco Francés & 60 & 3 & 8859 & 1996 & 980 \\
\hline & Corp Banca Argentina & 100 & 20 & 400 & 1999 & 85 \\
\hline Brazil & $\begin{array}{l}\text { Banco Excel-Económico } \\
\text { (now BBV Brasil) }\end{array}$ & 100 & 14 & 5000 & 1998 & 857 \\
\hline \multirow[t]{2}{*}{ Chile } & $\begin{array}{l}\text { Banco Hipotecario de } \\
\text { Fomento (BHIF), now }\end{array}$ & & & & & \\
\hline & BBV Banco BHIF & 55 & 6 & 2960 & 1998 & 218 \\
\hline Colombia & Banco Ganadero & 63 & 2 & 3526 & 1996 & 619 \\
\hline Mexico & BBV México (ex-Probursa) & 67 & 5 & 8556 & 1995 & 365 \\
\hline Peru & Banco Continental & 39 & 3 & 2864 & 1995 & 156 \\
\hline Puerto Rico & BBV Puerto Rico & 100 & 3 & 3580 & $\ldots$ & $\ldots$ \\
\hline Uruguay & Banco Francés & 58 & $\ldots$ & $\ldots$ & 1995 & $\ldots$ \\
\hline Venezuela & Banco Provincial & 51 & 1 & 4186 & 1997 & 432 \\
\hline Total & & & & 43026 & & 4500 \\
\hline
\end{tabular}

Source: Prepared by the authors on the basis of information published in BBV (1999a) and in the financial press.

a Argentaria has had a certain presence in Latin America, mainly in Argentina, Brazil, Chile and Paraguay, with the aim of boosting and financing trade between Spain and MERCOSUR.

Spanish group by international risk assessment agencies. In Latin America, there has not been any reduction in its profit levels in spite of the deterioration in macroeconomic conditions. This is basically because growth of the credit portfolio has been frozen and efforts have been concentrated on ways of obtaining resources from low-cost clients. In other words, there has been greater caution about credit risks and their coverage. There has thus been a big change in the structure of deposits in the BBV's Latin American operations, while strong expansion towards the pension fund management business has continued.

The BBV has a leading position in Spain as regards the management of such funds: its market share is over $14 \%$ and it manages assets worth some US\$ 5.3 billion for 467,000 clients (BBV, 1999a). In Latin America, this Spanish bank has found an interesting alternative for diversification and expansion in this activity, because of its great growth potential in the various markets of the region. At the end of 1998, the BBV was the second largest pension fund administrator in the region, with a weighted market share of $25 \%$ in the countries where it operates and a leading position in Argentina, Bolivia, Colombia, Mexico, Peru and El Salvador, managing some US\$ 4,570 million through six pension fund management companies with 4.6 million members.

On 13 May 1999 the BBV further strengthened and consolidated its leading position in Latin America through the indirect purchase of $40.74 \%$ of the largest pension fund management company in Chile, Provida. ${ }^{5}$ It thus began activities in Chile and Ecuador and strengthened its position in Mexico, Colombia, Peru and El Salvador (table 3). This operation, valued at some US\$ 266 million, was effected through an exchange of stock between the Chilean group Corp Group Pensions and the BBV. When it was completed, it trebled the assets managed by the BBV in Latin America to US\$ 15.4 billion, with a client base of over 8 million persons, and made the BBV the most important pension fund management company in the region, with a weighted market share of $26 \%$ in terms of the assets managed (BBV, 1999b). In October 1999, its share increased still further to $31 \%$

\footnotetext{
${ }^{5}$ Provida has 2.4 million members, manages assets worth US\$ 10.2 billion, and has five foreign branches (Colombia, Ecuador, Mexico, Peru and El Salvador). In Chile, Provida accounts for $40 \%$ of the members of the pension system.
} 
TABLE 3

Bilbao Vizcaya Argentaria group:

Presence in pension fund management in Latin America, 1999

\begin{tabular}{|c|c|c|c|c|c|}
\hline & Local company & $\%$ ownership & $\begin{array}{l}\text { Position in } \\
\text { local market }\end{array}$ & $\begin{array}{c}\text { Total value of } \\
\text { assets managed } \\
\text { (millions of dollars) }\end{array}$ & $\begin{array}{c}\text { Number of } \\
\text { members }\end{array}$ \\
\hline Argentina & Consolidar & 100 & 2 & 2213 & 1297000 \\
\hline Bolivia & Previsión & 72 & 1 & 937 & 250000 \\
\hline Chile & Provida & 47 & 1 & 10200 & 2400000 \\
\hline \multirow[t]{2}{*}{ Colombia } & Horizonte & 70 & 2 & 486 & 461000 \\
\hline & Porvenir $^{\mathrm{a}}$ & 20 & 1 & 586 & 841000 \\
\hline Ecuador & Génesis ${ }^{a}$ & 25 & 1 & 15 & 87000 \\
\hline \multirow[t]{2}{*}{ El Salvador } & Previsión & 51 & 2 & 7 & 134000 \\
\hline & Porvenir $^{\mathrm{a}}$ & 35 & 1 & 23 & 101800 \\
\hline Mexico & Profuturo & 40 & 3 & 514 & 1930000 \\
\hline Peru & Horizonte $^{a}$ & 75 & 2 & 416 & 511000 \\
\hline Total, BBV & & & & 15397 & 8012000 \\
\hline Argentina & Siembra & 50 & 1 & 2260 & 2500000 \\
\hline Bolivia & Futuro & $\ldots$ & $\ldots$ & $\ldots$ & $\ldots$ \\
\hline Colombia & $\ldots$ & $\ldots$ & $\ldots$ & $\ldots$ & $\ldots$ \\
\hline El Salvador & Máxima & 50 & $\ldots$ & $\ldots$ & $\ldots$ \\
\hline Panama & $\ldots$ & $\ldots$ & $\ldots$ & $\ldots$ & $\ldots$ \\
\hline Total Argentaria & & & & 4400 & 3500000 \\
\hline
\end{tabular}

Source: Prepared by the authors on the basis of BBV (1999a); AFP Provida (http://www.afpprovida.cl), and Fundación Argentaria (1999).

${ }^{a}$ Indirect participation through AFP Provida.

as a result of the merger with Argentaria. According to the BBV's estimates, it spent some US\$ 875 million in order to become the leading pension fund management company.

In addition, as in its market of origin, the BBV has looked for opportunities to invest in the stock of companies not related with the financial area, in which it remains a passive investor. Thus, it is estimated that in the next few years it could invest some US\$ 3.5 billion in emerging Latin American sectors such as telecommunications, energy and other services. At present, it has acquired some stock in Latin American companies in conjunction with companies in which it already has an interest, such as Iberdrola, Telefónica de España and Repsol. Particularly worthy of note is the BBV's participation in the consortium led by Telefónica which has acquired the São Paulo telephone company (Telesp) for US\$ 4,961 million.

To sum up, within a short space of time the BBVA has succeeded in establishing a solid leading position in several of the main lines of business of the Latin American financial sector (commercial banking and pension fund management). Thus, from being a re- gion where it had almost no presence, Latin America has become a natural extension of the main activities of this Spanish financial group, where it has repeated its corporate strategy and its rivalry with its main competitor in the Spanish market: the Banco Santander. Indeed, even before their merger the BBV and Argentaria had been rising in the scale of positions among the biggest banks in the world: between 1997 and 1998 the BBV rose from $50^{\text {th }}$ to $47^{\text {th }}$ place, while Argentaria rose from $72^{\text {nd }}$ to $67^{\text {th }}$ (The Banker, 1999). Moreover, some analysts consider that once it has consolidated its position in Latin America it may begin to redirect its expansion strategy towards the strengthening of its position in Europe. At the end of 1998 the BBV gained control of the fifth largest Italian banking group, the Banca Nazionale del Lavoro (BNL), for US\$ 500 million, and in May 1999 it was selected by the French authorities to form part of the hard core of the Crédit Lyonnais, controlling 3.8\% of the equity (figure 2). In early 2000 it is also said to be on the point of securing an alliance -and possible merger- with one of the biggest Italian groups, UniCredito Italiano. Thus, the merger of BBV and Argentaria does not appear to represent any impedi- 
ment to its expansion in the southern Euro zone countries and could even further it.

\section{The Banco Santander and the Banco Central Hispano: two rivals with different business strategies which ended up merging with each other}

At the end of 1998, the Banco Santander had $14 \%$ of the Spanish market and was the second largest financial group in Spain. The Grupo Santander is widely represented internationally, with nearly 5,800 offices in 32 countries, serving some 17 million clients. Of the present large Spanish banks, the Banco Santander is that which has carried on its international expansion strategy for the longest time, displaying a marked capacity for innovation and flexibility (Burns and Weeks, 1998) as well as a clear desire to gain control in its overseas operations. In this respect, the extensive international experience and strong leadership exerted by the president of this bank, Emilio Botín, has caused the Banco Santander to prefer to act on its own -without local partners- in its Latin American operations.

Its presence in Latin America goes back to the early 1950s, after which it grew at a modest rate and concentrated on the Southern Cone countries, especially Chile. From 1996 on, however, it embarked on an active strategy of expansion through the acquisition of a large number of banks all over the region. At the beginning of 1996, its operations in the region generated only $8 \%$ of the total operating profits of the Grupo Santander, but by the end of 1998 this proportion had risen to over 40\%. In 1998 Latin America accounted for $27 \%$ of its assets, $30 \%$ of its branches and $53 \%$ of its employees.

The year 1997 was particularly important for the expansion strategy of the Grupo Santander in Latin America, because in that year it incorporated banks in Argentina, Brazil, Colombia, Mexico and Venezuela into its activities in the region (table 4). This first phase of the Banco Santander's expansion strategy involved the acquisition of half a dozen banks in five countries in a little over a year, for an outlay of over US\$ 3.5 billion. According to some analysts, this acquisition strategy was determined to some extent by the likewise rapid expansion of the BBV in the region. The Grupo Santander was concerned about the fact that the most interesting assets were being snapped up by its competitors -especially the BBV- thus limiting the available opportunities and driving up prices, so it speeded up its purchase strategy.

In 1998 there were two events which marked the culmination of the first phase of its Latin American expansion strategy: the sale of the $8.8 \%$ share that the Banco Santander had in the United States bank First Union Corp. ${ }^{6}$ and the purchase of the Banco do Noroeste in Brazil. The Spanish group used US\$ 1.5 billion of the added value generated by the first-named transaction, plus US\$ 300 million of its profits from the preceding year, to finance its investments in Latin America. With these acquisitions, the Grupo Santander now carries on banking activities in nine countries of the region (table 4): Chile, Puerto Rico, Peru and Uruguay, plus the five countries mentioned in the previous paragraph. Thus, according to executives of the Group, the programme of acquisitions in Latin America is now practically over, and no further major purchase is now envisaged in the short term, although this does not rule out small acquisitions in the financial services industry, in order to increase the Group's capacity in the area of insurance and pension funds or to add further branches to the existing network.

This strategy has also been the subject of criticism, however. Increasing the Group's Latin American subsidiaries from three to nine in a little over one year caused some concern among shareholders. On the one hand it increased the Banco Santander's exposure in an area of higher risk, and on the other it made the management of the Group more complex. However, the executives of the bank have consistently defended the strategy adopted in Latin America and have justified the policy of acquisitions, maintaining that after analysing a large number of banks in the region they selected the best.

The Banco Santander has tried to secure a strong and homogeneous presence in the region. This objective has gradually been achieved, and it only remains for the Group to improve its position in the markets of Brazil, Colombia, Peru and Mexico. According to some analysts, the Banco Santander's operations in those countries are too small to generate a critical

\footnotetext{
${ }^{6}$ In 1991 the Banco Santander had purchased $13.3 \%$ of First Fidelity Bancorporation, a small New Jersey bank without a nationwide presence, for US\$ 650 million. In June 1995, First Fidelity merged with First Union, and the Banco Santander became the biggest individual shareholder in First Union. In June 1997, the Santander Group sold its share for US\$ 2,160 million.
} 
TABLE 4

Santander Central Hispano group:

Presence in the Latin American banking market, 1999

(Percentages and millions of dollars)

\begin{tabular}{|c|c|c|c|c|c|c|}
\hline & Local bank & $\%$ ownership & $\begin{array}{l}\text { Position in } \\
\text { local system }\end{array}$ & $\begin{array}{c}\text { Total value } \\
\text { of assets, } \\
\text { December } \\
1998 \\
\end{array}$ & $\begin{array}{c}\text { Year of } \\
\text { entry }\end{array}$ & $\begin{array}{c}\text { Purchase } \\
\text { price }\end{array}$ \\
\hline \multicolumn{7}{|c|}{ Banco Santander } \\
\hline Argentina & Banco Río de la Plata & 51 & 2 & 9175 & 1997 & 807 \\
\hline \multirow[t]{3}{*}{ Brazil } & Banco Santander Brasil (formerly & & & & & \\
\hline & Banco Geral do Comercio) & 100 & 11 & & 1997 & 389 \\
\hline & Banco Noroeste ${ }^{a}$ & 76 & 9 & 9357 & 1998 & 564 \\
\hline Chile & Banco Santander Chile & 86 & 2 & 9709 & 1996 & 718 \\
\hline Colombia & Banco Santander Colombia & 60 & 6 & 2086 & 1997 & 236 \\
\hline Mexico & Banco Santander Mexicano & 71 & 5 & 9808 & 1996 & 500 \\
\hline Peru & Banco Santander Perú & 100 & 6 & 951 & 1995 & 90 \\
\hline Puerto Rico & Banco Santander Puerto Rico & 78 & 2 & 6468 & 1996 & 366 \\
\hline Uruguay & Banco Santander Uruguay & 100 & 3 & 740 & & $\ldots$ \\
\hline Venezuela & Banco de Venezuela & 98 & 3 & 2008 & 1997 & 380 \\
\hline Total & & & & 50302 & & 4000 \\
\hline \multicolumn{7}{|c|}{ Banco Central Hispano } \\
\hline \multirow[t]{2}{*}{ Argentina } & Banco Tornquist ${ }^{b}$ & 100 & 16 & 1165 & 1996 & 93 \\
\hline & Banco de Galicia y Buenos Aires & 10 & 1 & 14100 & 1998 & \\
\hline Bolivia & Banco Santa Cruz & 90 & 1 & 1336 & 1998 & 180 \\
\hline Chile & Banco Santiago $^{b}$ & 44 & 1 & 10430 & 1991 & 294 \\
\hline \multirow[t]{2}{*}{ Mexico } & Grupo Financiero Bital (includes & & & & & \\
\hline & Banco Internacional de México) & 8 & 4 & 10000 & & 37 \\
\hline Panama & Centrobanco Hispano Panamá & 100 & $\ldots$ & $\ldots$ & $\ldots$ & $\ldots$ \\
\hline Paraguay & Banco de Asunción ${ }^{b}$ & 85 & 5 & 151 & 1996 & 10 \\
\hline Peru & Banco del Sur (Bancosur) ${ }^{b}$ & 90 & 5 & 1042 & 1996 & 71 \\
\hline Puerto Rico & $\mathrm{BCH}$ Internacional & 100 & $\ldots$ & 718 & $\ldots$ & \\
\hline Uruguay & Eurobanco S.A. & 100 & $\ldots$ & $\ldots$ & 1996 & 8 \\
\hline Total & & & & 38942 & & 1300 \\
\hline
\end{tabular}

Source: Prepared by the authors on the basis of data from Grupo Santander (1999a), BCH (1999), Latin Trade (1998) and the financial press.

${ }^{\text {a }}$ During 1998 a process of merging the different branches of the Banco Santander in Brazil was begun.

b The BCH group consolidated its presence in Latin America through its participation in the O'Higgins Central Hispano (OHCH) company. As from 1996, in coordination and joint management with the Chilean Luksic business group, it has carried on activities in Argentina, Chile, Paraguay and Peru. At the end of 1998, the total assets of the banks forming part of the company came to some US\$ 12.8 billion, with US\$ 1,233 million of own funds and a network of 276 offices with a staff of 7,511 persons. On 12 February 1999 , the $\mathrm{BCH}$ announced that it wished to put an end to its association with the Luksic Group in the OHCH company. The BCH valued the company at US\$ 1.2 billion, of which the Spanish group was entitled to US\$ 600 million. This valuation gave rise to conflicts, because when it merged with the Banco Santander the $\mathrm{BCH}$ estimated its share of $\mathrm{OHCH}$ at some US\$ 400 million. The Chilean group was given two months to take a decision and finally accepted the US\$ 600 million offered for its $50 \%$ share of $\mathrm{OHCH}$.

mass of income (Falcão Filho, 1997). In Brazil, at least in the short term, the Group will have to grow without making acquisitions until such time as there is a major restructuring of the Brazilian banking system. In Mexico -the other great market of the region- the Banco Santander has had some problems associated with the local banking crisis. Now, however, after an injection of capital from Head Office, the Mexican subsidiary is one of the soundest institutions in that country and is getting ready to increase its share of the market as from the year 2000 (Hernández, 1999).
The Banco Santander's strategy has always been to secure majority control of the institutions acquired. It thus has an average share of over $78 \%$ of the equity of its acquisitions in Latin America (Grupo Santander, 1999a). Furthermore, by agreement with its shareholders, the institutions acquired in Latin America must have a level of profits of at least 20\%. According to the Grupo Santander's own forecasts, however, the profit margins of its Latin American branches are likely to go down significantly as competition increases in the markets of the region. Even so, the Group hopes to increase its in- 
come -by raising the efficiency of its Latin American subsidiaries- as the region recovers from the effects of the international financial crisis and growth and economic stability are restored.

Taking advantage of its experience in the Spanish market, the Banco Santander has carried out an intensive campaign to introduce its corporate image, promote its products which have been successful in Spain -such as the SuperCuenta, SuperDepósito, SuperHipoteca and SuperCrédito- and increase its market share in the region. Like other banks which have expanded in Latin America -the BBV and the Hong Kong and Shanghai Banking Corporation (HSBC) - the Banco Santander's high-profile campaign has forced other actors, both local and foreign, to redefine their strategies and commitments, and it has raised the level of competition in a sector which is of crucial importance for the economic health and stability of the region.

Parallel with the expansion of the Grupo Santander, another smaller Spanish bank -the Banco Central Hispano $(\mathrm{BCH})-$ began its internationalization in Latin America. ${ }^{7}$ The basic strategy of the $\mathrm{BCH}$ in the region was to secure majority shares in local institutions in association with strategic partners who would take care of the local management of the operations. In 1996 the $\mathrm{BCH}$ embarked on an ambitious process of expansion in the region which revolved mainly around its strategic alliance with the Chilean Luksic Group, through its share in the O'Higgins Central Hispano company $(\mathrm{OHCH})$. Thus, the $\mathrm{BCH}$ was present in Argentina, Chile, Peru and Paraguay in a 50/50 association with the Luksic Group. In its operations in the region, a particularly important place was occupied by its activities in Chile, where, through the Banco Santiago, it was a leader in one of the most competitive markets of the region (table 4). As a result of financial difficulties and greater competition in its market of origin, the $\mathrm{BCH}$ concentrated its efforts on Spain and left the Luksic Group to run the Latin American operations of the $\mathrm{OHCH}$, which incorporated institutions in Argentina and Peru. This financial group thus came to control assets worth some US\$ 13 billion in the region (Sullivan, 1998).

\footnotetext{
${ }^{7}$ At the end of 1998, the $\mathrm{BCH}$ was the third largest institution on the Spanish banking market. Of this "Big Three", it was the least internationalized, having concentrated its efforts in this respect in Latin America, which, in 1998, accounted for 13\% of its assets, $11 \%$ of its branches and $28 \%$ of its employees.
}

After achieving a rapid recovery in Spain, the $\mathrm{BCH}$ began to take a more active part in the $\mathrm{OHCH}$ company, seeking to continue its expansion strategy in the region with fresh resources. In March 1998, in order to step up its growth in the region, the $\mathrm{BCH}$ announced an increase of US\$ 1,050 million in its capital. Its Chilean associates were reluctant to participate in new acquisitions, however, as they wanted to concentrate their efforts on consolidating the Banco Santiago. In view of the difficulty of finding new partners, ${ }^{8}$ the $\mathrm{BCH}$ decided to continue increasing its presence in the region on its own, acquiring substantial packages of shares in the most important banks of Argentina and Bolivia (table 4).

Early in 1999, the BCH merged with the Banco Santander to create a new institution with a different strategic orientation from that which the $\mathrm{BCH}$ had previously been applying in Latin America. The top executives of the group finally agreed that the main strategic guidelines of the new institution should give priority to strengthening retail, corporate and business banking in Spain, increasing the contribution of the group's international activities to profits (with special emphasis on the European and Latin American markets), and seeking the ongoing optimization of the group's industrial holdings (BCH, 1999, and Grupo Santander, 1999a). This meant, among other things, the dissolution of the association with the Chilean Luksic Group and the absorption of the assets of the $\mathrm{OHCH}$ company by $\mathrm{BSCH}$, which caused some problems of overlapping in regional operations. The growth of the two groups' operations in Latin America has been crucial for their rise in status among the largest banks in the world: thus, between 1997 and 1998 the Grupo Santander rose from $40^{\text {th }}$ to $37^{\text {th }}$ place and the $\mathrm{BCH}$ from $107^{\text {th }}$ to $98^{\text {th }}$ (The Banker, 1999).

Like the BBVA, the Grupo Santander has not concentrated exclusively on banking proper but has also diversified into other financial activities such as investment banking and pension fund management. In this latter field (table 5), it is the leader in Spain with $15.6 \%$ of the market, while in Latin America it manages pension funds worth some US\$ 6 billion

\footnotetext{
${ }^{8}$ The $\mathrm{BCH}$ did not succeed in persuading the Banco Comercial Português (BCP), its European associate, to join in its expansion plans in Latin America. Indeed, the BCP has even tried to dispose of its $8.5 \%$ share in the Banco Internacional: a share which it acquired in association with the $\mathrm{BCH}$, which has an $8.25 \%$ share in the Bital Group, the owners of the Mexican bank in question.
} 
TABLE 5

Santander Central Hispano group: ${ }^{\text {a }}$

Presence in pension fund management in Latin America, 1999

\begin{tabular}{|c|c|c|c|c|c|}
\hline & Local company & $\%$ ownership & $\begin{array}{l}\text { Position in } \\
\text { local market }\end{array}$ & $\begin{array}{c}\text { Total value of } \\
\text { assets managed } \\
\text { (millions of dollars) }\end{array}$ & $\begin{array}{c}\text { Number of } \\
\text { members }\end{array}$ \\
\hline Argentina & AFJP Orígenes & 30 & 1 & 1983 & 1460117 \\
\hline Chile & AFP Summa Bansander & 100 & 4 & 3439 & 426239 \\
\hline \multirow[t]{2}{*}{ Mexico } & Afore Santander Mexicano & 100 & 2 & 363 & 1968585 \\
\hline & Afore Génesis ${ }^{b}$ & 100 & 12 & 30 & 141542 \\
\hline Peru & AFP Nueva Vida & 80 & 5 & 163 & 127338 \\
\hline Uruguay & Santander AFAP & 100 & 4 & 41 & 65105 \\
\hline Total & & & & 6019 & 4188926 \\
\hline
\end{tabular}

Source: Prepared by the authors on the basis of Grupo Santander (1999a).

a Like other Spanish banks, the BCH sought to diversify into other lines of business in the region, especially pension fund management. With its traditional banking partners, it entered the pension fund management market in Chile (with the Luksic Group) and Mexico (with the Banco Comercial Português), but it did not have a successful experience and in mid-1998 it liquidated its share in the Chilean pension fund management company Qualitas.

b In July 1998 the Santander Group acquired Afore Génesis for US\$ 27 million, subsequently merging it with Afore Santander.

in Argentina, Chile, Mexico, Peru and Uruguay, with a total of over 4.3 million clients (Grupo Santander, 1999b).

In the mid-1990s the Grupo Santander opened an office in New York with the aim of becoming one of the three main investment banks for business deals related to Latin America and thus complementing the network of banks that it was beginning to establish in the region. It quickly won the confidence of Latin American companies and governments wishing to gain access to international capital markets, but it was not able to take advantage of its strong position in the markets of the region to generate profitable deals in New York (Moore, 1999). It performed well in securities brokerage on secondary markets, despite the low profit margins, but it only obtained rather unsatisfactory results in more profitable operations such as securities issues, going public, or mergers and acquisitions. The Grupo Santander therefore de- cided to reduce its presence in New York and concentrate on its local markets, concluding that there was excess capacity in the field of Latin American investment banking.

Finally, like the BBVA, the BSCH began to step up its expansion process in Europe. At the end of 1999, the BSCH supported the Royal Bank of Scotland (in which it has a 10\% share) in its US\$ 40,689 million offer for the National Westminster Bank. If this operation succeeded, the BSCH would obtain $6.5 \%$ of the new merged institution and would improve its position in the United Kingdom financial market. In order to finance the operation, it would increase its capital by $4.5 \%$, to be offered to some of its associates already referred to: Société Générale, Commerzbank and San Paolo-IMI. This would enable it to establish closer relations with Société Générale, which would buy most of the new shares and thus gain a seat on the board of directors of BSCH (Expansión, 1999c). 


\section{IV}

\section{An expansion process not devoid of difficulties}

In 1998 and the first half of 1999, banking in Spain operated in a dual environment. On the one hand, the Spanish economy was performing satisfactorily, with $4 \%$ growth and the lowest interest rates in decades, but on the other hand the worsening of the international crisis due to the situation in Russia and Asia hit the Latin American markets hard. Against this background, the stock exchange value of the biggest Spanish banks (the BBV and the Banco Santander) deteriorated, and this adversely affected their operations in the region to some extent. Despite these adverse conditions, however, both these institutions closed the exercise with good results, attributable above all to their performance in the first part of 1999. By the beginning of December 1998, both banks had recovered and reported increases in profits of $80 \%$ and $71 \%$ respectively (Durán, 1999). Indeed, the high level of profitability of their Latin American operations has enabled them to cover the cost of a large part of their investments in the region. The top executives of these Spanish financial groups have continued to declare their commitment to expansion in Latin America. Thus, they are expected to embark on a second phase of this expansion strategy, designed to increase the efficiency and competitiveness of their banks in the region.

The stocks of the BBV and the Banco Santander fell by almost $50 \%$ between July and September 1998 (figure 3), and the risk rating agencies lowered their forecasts for these banks because of their over-exposure in Latin America. In spite of the strong reaction of the markets, however, these Spanish institutions were apparently prepared for even worse situations (Calderón and Casilda, 1999). In their Latin American banks they maintained an average level of provisions against unpaid loans of over $100 \%$, although in fact the rate of delinquency was quite low: at the end of 1998 the percentage of overdue loans in the region was $5.6 \%$ for the BBV and $3.7 \%$ for the Banco Santander. In mid-1998 they also put into effect stringent programmes of sound management and reduction of costs.
In addition to the reactions of the market, these operations also had their critics inside Spain. The growing importance of the Latin American operations of the country's two main banks gave rise to concern, mainly because of the vulnerability that the economies of the region have shown to upsets on international financial markets. Thus, the Banco de España considered that the two institutions' Latin American acquisitions involved considerable risks, much greater than those deriving from traditional banking operations, and even urged the main Spanish banking institutions to make a very careful evaluation when purchasing new assets and to lay stress on their quality rather than seeking short-term gains.

At the same time, the impending entry into effect of the Euro on 1 January 1999 further heightened the competitive pressures on the Spanish banking institutions. Consequently, as they needed to make adjustments in their global strategy, the possibility of mergers between Spanish banks or with some European partner became more likely.

Thus, on 15 January 1999 the Banco Santander merged with the $\mathrm{BCH}$ to form a new institution called the Banco Santander Central Hispano (BSCH). This new bank became the leader in the Spanish market and one of the most important banks at the European level, and its position in the face of future alliances in the Euro zone was considerably strengthened. After this agreement, the $\mathrm{BSCH}$ became the biggest foreign financial group in Latin America, leaving the $\mathrm{BBV}$ in second place and displacing other long-established banks in the region, such as the United States institutions Citibank and BankBoston and the Dutch bank ABN Amro. At the same time, the merger tranquillized the markets and the stock market value of the new Spanish group began to register a rapid and lasting recovery (figure 3 ).

According to the financial press, one of the main losers in all this was the BBV, and it was expected to react to these developments. Finally, on 19 October 1999, after nine months of continual rumours, the $\mathrm{BBV}$ and Argentaria merged to form a new institu- 
FIGURE 3

Banco Bilbao Vizcaya and Banco Santander:

Evolution of share prices, 1995-1999

(In pesetas)

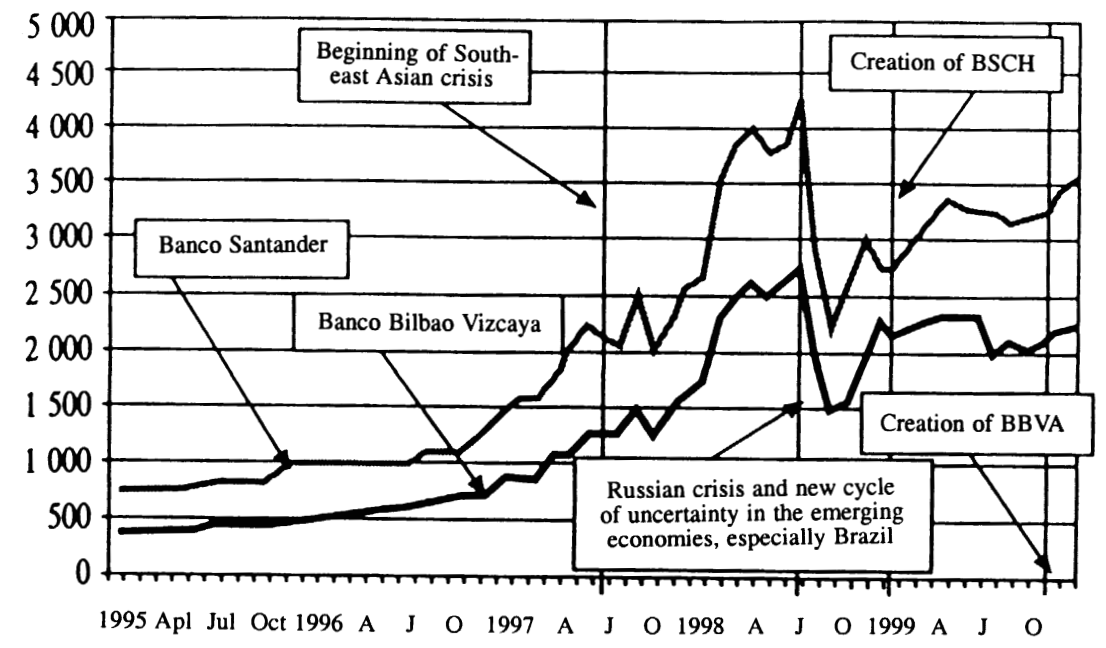

Source: Prepared by the authors on the basis of information from the Madrid Stock Exchange.

tion: the Banco Bilbao Vizcaya Argentaria (BBVA). With this operation, the Spanish banking system was consolidated around two great institutions, although the BSCH continues to be the leader: in the area of loans it has around $20 \%$ of the market, compared with the BBVs's $17 \%$, while in terms of deposits each institution has around 15\% of the market (Expansion, 1999a). The BBVA also became a very important actor at the European level, with a market capital level slightly above that of the BSCH.

Although the merger complemented and strengthened the new bank's presence in Latin America, it also gave rise to some difficulties: basically, it increased the level of banking concentration and revealed some shortcomings in the regulatory frameworks of the markets in which these institutions already operate or expect to operate in the future. Thus, in some countries of the region the economic authorities are taking a hard look at the dominant position that the two Spanish banks have acquired (figure 4). If it is considered that the degree of concentration affects or harms free competition, they may be obliged to divest themselves of some assets. In markets such as Argentina, Chile and Venezuela, the BBVA has achieved a bigger share than it has in Spain: indeed, this bank and the BSCH have be- come the only two banks in the world which have achieved such a position outside their natural market (Calderón and Casilda, 1999).

The most serious problem created by the establishment of the BSCH is in Chile, where the Banco Santiago and the Banco Santander Chile occupy the first and second places at the national level, with a joint market share of nearly one-third (28\% of the system's loans), which may be against the anti-monopoly regulations. This case revealed the shortcomings of the national regulatory frameworks for coping with an increasingly globalized international market. At the end of April 1999, the BSCH finally dissolved its alliance with the Luksic Group, which it paid US\$ 600 million for its 50\% share of the joint activities in Latin America. With this operation, the BSCH controlled $44 \%$ of the Banco Santiago and $86 \%$ of the Banco Santander Chile; it also came to an agreement with the Central Bank of Chile to acquire over three years the $34.5 \%$ share that the latter had in the Banco Santiago. Furthermore, the Banco de España does not find it very acceptable that a Spanish bank, which it is responsible for supervising, indirectly has $30 \%$ of its banking risks in Chile or another foreign country, for this means that any upset affecting the banking market of the host 
FIGURE 4

Banco Santander Central Hispano and Banco Bilbao Vizcaya:

Presence in Latin America, $1999^{a}$

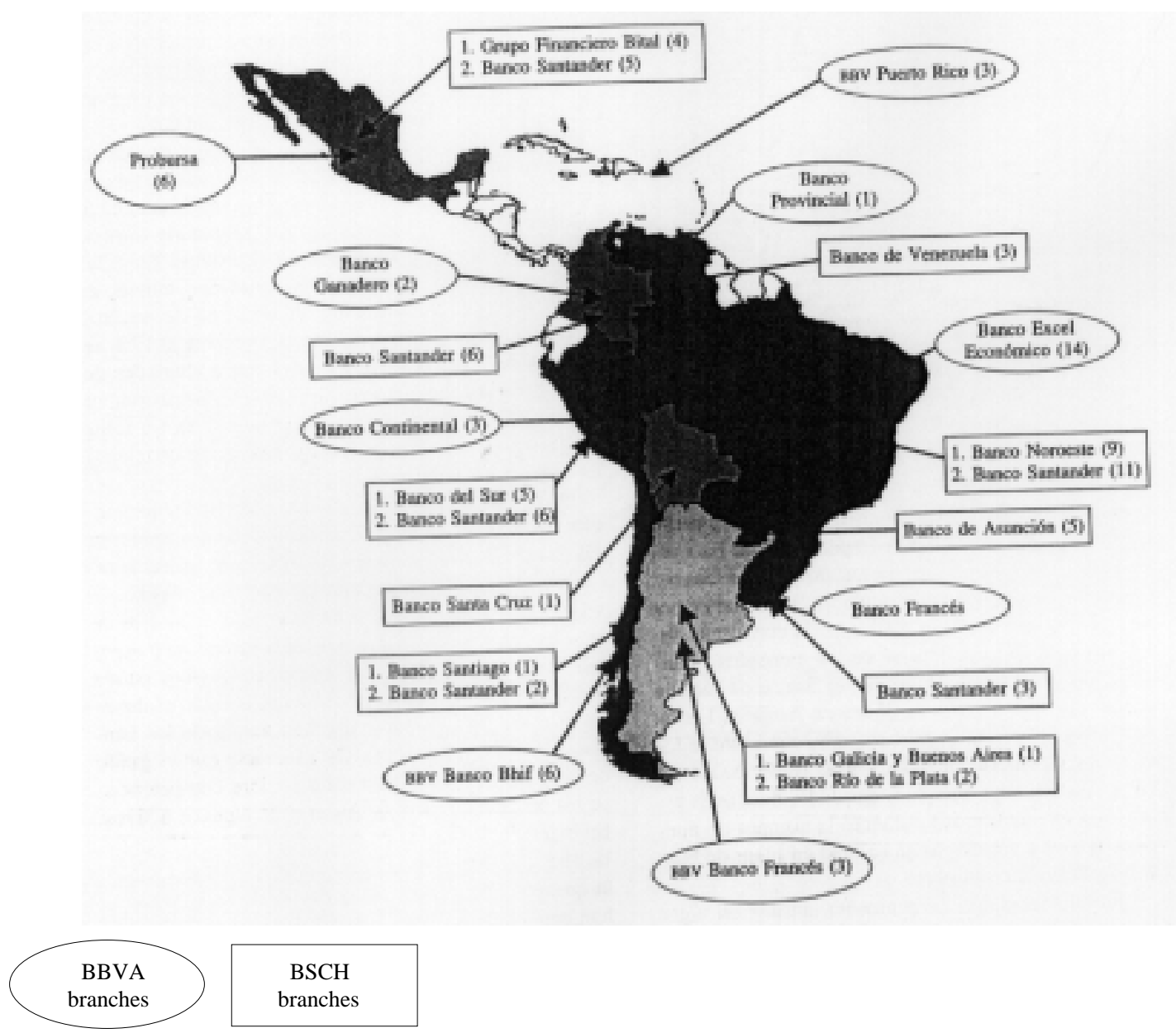

Source: Prepared by the authors on the basis of Calderón and Casilda, 1999.

a Numbers in brackets indicate position in the national banking system.

country can affect that bank and, ultimately, the Spanish banking system too.

In these circumstances, the $\mathrm{BSCH}$ came to an agreement with the Chilean government and parliamentary authorities in which it undertook to run the two banks it owns in the country separately (the Banco Santiago and the Banco Santander Chile) and to put off a possible merger of the two. It also agreed to reduce its share in the Chilean market, so that its decision as to which of the banks it intends to sell is awaited. This is a complicated matter, as these are banks worth a great deal of money (US\$ 1.8 billion for the Banco Santiago and US\$ 1.3 billion for the Banco Santander Chile), but it is nevertheless expected that this sale will take place in the short term. Analysts wager that it will opt for strengthening the Banco Santander and carving up the Banco Santiago for subsequent resale. This operation would include the transfer from the Banco Santiago to the Banco Santander of the whole of its $100 \%$ compatible portfolio (which should amount to about $8 \%$ of the whole), in order to raise the latter bank's market 
share by a similar amount. Among possible purchasers would be Citibank and ABN Amro, with the possibility that the BSCH might sell the Banco Santiago to its strongest competitor, the BBV, being almost completely ruled out. Finally, in January 2000 the $\mathrm{BSCH}$ announced its decision to reduce its participation in the Chilean market. According to some speculations in the press, the $\mathrm{BSCH}$ is preparing to merge the two banking institutions, which would mean an immediate reduction of four points (El Mercurio, 2000).

In the case of the merger between the BBV and Argentaria, the situation has been somewhat different (figure 4). This union would not give rise to any major problems in Latin America, because of the almost total lack of any overlapping of the two Spanish financial groups' operations in the region. The BBV has concentrated on commercial banking and, more recently, on pension fund management. Right from the start, Argentaria was unwilling to invest large amounts of resources in the purchase of other banks, so it opted for a line of business which it knew very well and did not involve many risks: private pension fund management.

For the Latin American countries it would be desirable -quite apart from the problems of bank concentration- that this massive entry of foreign banks, and especially of Spanish institutions, should further the achievement of various objectives, including the following:

- Strengthening the local financial systems through the greater capacity of the foreign banks to obtain resources at lower cost on international markets.

- Reducing intermediation spreads through the increase in competition and the fact that the foreign banks are accustomed to working at lower

\section{V}

\section{Conclusions}

After more than ten years of a broad-ranging and extensive process of liberalization and financial deregulation, the situation in the Latin American banking, insurance and pension fund markets has been completely changed by the massive presence of global financial institutions. The great Spanish banks have profit margins $3 \%$ in the United States and the United Kingdom, compared with $6.3 \%$ in Brazil, for example). If there were such a reduction, the financial costs of borrowers would also be reduced.

- Increasing competition and reducing operating costs, which would oblige the local banks to raise their efficiency in order to reduce their vulnerability.

- Increasing the level of financial intermediation through a greater supply of new and more sophisticated products from the institutions operating in local markets.

So far, the most obvious result has been the strengthening of local markets, which, in the face of two large-scale international financial crises (in late 1994 and mid-1997), have shown themselves to be less vulnerable than in past crises (especially the external debt crisis). Perhaps the most difficult case continues to be that of Mexico. With regard to the benefits of increased competition and their transfer on to clients, the results have been varied. In general, the intermediation spreads of foreign banks in their Latin American operations continue to be high, unlike the spreads in their markets of origin, and although operating costs have been sharply reduced the cost of credit has not gone down significantly.

To sum up, in a setting which has undergone many changes the internationalization strategy of the main Spanish banks has given rise to heated controversy. In Latin America, Spain and the European Union, the political and economic authorities, businessmen, shareholders, markets and clients have all expressed their different points of view about the unprecedentedly rapid and far-reaching phenomenon of the expansion of the Spanish banks in the main areas of business of the Latin American financial sector. been central actors in this process and have become leaders in most of the countries and segments of financial business in the region (figure 4). In the early 1990 s, these banks, together with some public enterprises such as Telefónica and Iberia, led the process of internationalization of Spanish business. Now, the 
Spanish banks come to Latin America for their own interests rather than those of their clients, and the Spanish public enterprises which are most active in the region have been totally privatized.

The international financial crisis which began in 1997 and its strong impact on the region -particularly in Brazil- did not alter this trend, for the international banks continued to increase their presence in the markets of the region (figure 4). Firstly, many of the small and medium-sized banks in Latin America have not been able to adapt to the new situation, which could mean their disappearance or acquisition by foreign companies, and secondly, some of the larger institutions have sought the financial support of important foreign companies in order to be better prepared for the expected increase in competition in the years to come.

In general terms, the first stage in the expansion of the big Spanish financial institutions in Latin America is now over. In the main line of business, commercial banking, the BBVA and the $\mathrm{BSCH}$ both occupy similar positions, with a strong presence in most of the markets of the region. The main unfinished business for them is their expansion in the Brazilian market and, to a lesser extent, that of Mexico. They have also embarked on an active process of diversification, combining investments in banking with others in insurance, in pension funds, and more recently in private health systems.

The strong impact that the growing exposure of the main Spanish banks in Latin America has had on their stock market value has forced them to make some adjustments in their internationalization strategy. In Latin America, in view of both the reduction in profit margins due to the stronger competition and the more marked relative external vulnerability of those markets, they have had to apply active programmes to put their branches in the region on a sounder footing and improve their productivity, and in Europe, as a result of the increase in average sizes and in competitive pressures, the Spanish banks appear to be embarking on an expansion strategy which will put them in a better position to cope with future developments in this common market.

From the Latin American standpoint, the entry of foreign banks, and especially of the Spanish institutions, has helped to stimulate and modernize the financial systems of the region. In general, the foreign institutions have introduced new instruments and technology, have increased the levels of competition -with direct effects on the availability and cost of credit- and have made the local financial systems stronger and more stable. They have also brought some difficulties, however, such as the increase in concentration and the slowness with which the benefits of the greater competition and efficiency of the Latin American financial markets have been passed on to clients.

This broad presence of the Spanish banks, together with the active expansion of Spanish non-financial enterprises in the main Latin American markets, has caught the attention of regional and multilateral agencies, and at the same time it has shown up the limitations of national regulatory frameworks for coping with the increasing globalization of international markets. Thus, decisions taken in Europe affect users in Latin America and elsewhere, giving rise to reactions at various levels whose final results have yet to be seen.

(Original: Spanish)

\section{Bibliography}

AFP Provida ("Provida" pension fund management company): http://www.afpprovida.cl

Banco de España (1999): Boletín económico, Madrid, April.

BBV (Banco Bilbao Vizcaya) (1999a): Informe anual 1998, Bilbao, Spain.

-(1999b): Relación con inversores, Bilbao, Spain (http://www.bbv.es).

BCH (Banco Central Hispano) (1999): Informe anual 1999, Madrid.
Burns, R. and S. Weeks (1998): Man of the year: Emilio Botín, Latin Finance, No. 95, Miami, Florida, Latin American Financial Publications, March.

Calderón, A. (1999a): Las renovadas estrategias de los inversionistas extranjeros en América Latina y el Caribe: la participición de la empresa española, Sintesis, No. 29/30, Madrid, Asociación de Investigación y Especialización sobre Temas Iberoamericanos (AIETI). 
- (1999b): Estrategia de las inversiones españolas en América Latina, Economía exterior, No. 9, Madrid, Estudios de Política Exterior, SA.

Calderón, A. and R. Casilda (1999): Grupos financieros españoles en América Latina: una estrategia audaz. en un difícil y cambiante entorno europeo, "Desarrollo productivo" series, No. 59, Santiago, Chile, Economic Commission for Latin America and the Caribbean (ECLAC), September.

Calderón, A. and Z. Vodusek (1998): Foreign direct investment in Latin America and the Caribbean: An overview, in IDB (Inter-American Development Bank), Foreign Direct Investment in Latin America: Perspectives of the Mayor Investors, Madrid, Institute for European-Latin American Relations (IRELA).

Casilda, R. (1997): La banca española. Análisis y evolución, Madrid, Ediciones Pirámide.

Casilda, R., P. Lamothe and M. Monjas (1997): La banca y los mercados financieros, Alianza Universidad, textos No. 166, Madrid, Editorial Alianza.

Durán, J. J. (1999): Multinacionales españolas en Iberoamérica. Valor estratégico, Madrid, Universidad Autónoma de Madrid, Centro Internacional Carlos V/Ediciones Pirámide.

ECLAC (1998): Foreign Investment in Latin America and the Caribbean, 1998 Report, LC/G.2042-P, Santiago, Chile.

(2000): Foreign Investment in Latin America and the Caribbean, 1999 Report, LC/G.2061-P, Santiago, Chile.

El Mercurio (2000): Santiago, Chile, 9 January.

Expansión (1999a): Mexico City, Grupo MEDCOM, S.A. de C.V., 19 October.

(1999b): Mexico City, Grupo MEDCOM, S.A. de C.V., 20 December.

-(1999c): Mexico City, Grupo MEDCOM, S.A. de C.V., 30 November.

Falcão Filho, A. (1997): Cambio de marcha. Banco Santander no quiere comprar más. ¿Se lo permitirá el mercado?, América economía, No. 126, Rio de Janeiro, Nabei Ltd., December.
Freres, C. (1991): Spain rediscovers the Americas, Latin Finance, No. 30, Miami, Florida, Latin American Financial Publications, August.

Fundación Argentaria (1999): Informe anual 1998, Madrid.

Gazeta Mercantil Latino-Americana (1999): Relatório da Gazeta Mercantil Latino-Americana: Bancos, São Paulo, 28 June- 4 July.

Grupo Santander (1999a): Informe anual 1998, Madrid.

(1999b): Resultados de 1998 del Grupo Santander, Madrid (http://www.bancosantander.es).

Hernández, U. (1999): Banca extranjera: nuevos conquistadores, Expansión, vol. 30, No. 773, Mexico City, Grupo MEDCOM, S.A. de C.V., 1 September.

Latin Trade (1998): Los 100 mayores bancos latinoamericanos, Miami, Florida, Freedom Magazines, Inc., July.

Moore, L. (1999): Santander investment: radiografía de un repliegue, América economía, Rio de Janeiro, Nabei Ltd., 17 June.

Rodríguez, M. (1998): La expansión de las empresas españolas en Iberoamerica: el caso de la banca, Economía exterior, No. 7, Madrid, Estudios de Política Exterior, SA.

Salomon Smith Barney (1998): Foreign financial institutions in Latin America, New York, Latin America Equity Research.

- (1999): Update on Foreign Financial Institutions in Latin America, New York, Latin America Equity Research, March.

Sullivan, T. (1998): Voy de compras, ¿me acompañas?, América economía, No. 134, Rio de Janeiro, Nabei Ltd., 4 June.

The Banker (1999): The 1000 world banks, London, Financial Times, July.

The Economist (1999): London, The Economist Newspaper, NA, Incorporated, 27 November-2 December.

Uriarte, P. L. (1997): La estrategia de expansión del BBV en América Latina, Bilbao, Spain, BBV, March.

Valero, F. (1994): La internacionalización de la empresa bancaria española, Economistas, año XII, No. 62, Madrid, Colegio de Economistas de Madrid. 